\title{
CAREER ADVANCEMENT AND GENDER EQUITY IN ACADEMIA
}

\author{
Irina Kerimova \\ Westminster International University in Tashkent, Uzbekistan
}

\begin{abstract}
This paper aims at exploring gender equality in career advancement. The literature suggests that family impedes females' career progression as in Uzbekistan females mostly prioritize child-rearing over career building. However, there is no evidence that single female academics are more successful in their careers than those with family. Meanwhile, males are more likely to have career progression due to the culturebound domination of men over women. To conduct the research, 76 non-randomly selected academic staff of Westminster International University in Tashkent (WIUT) were surveyed via a questionnaire. The analysis found no statistically significant difference between female and male career advancement. Due to the time constraints as one of the limitations of the study, the research cannot cover a big population to conclude county-wide; notwithstanding, the present research is a steppingstone for further investigation on such a thrilling and up-to-date topic as gender equality.
\end{abstract}

Keywords: female, women, career advancement, promotion, academia, university, gender, inequality

DOI: http://dx.doi.org/10.15549/jeecar.v8i3.593

\section{PROBLEM DEFINITION}

In contemporary times men and women have equal access to education and work (Parker \& Pollock, 2013). However, UNESCO (2008) reports that relative gender parity in education does not guarantee gender equality at work. One of the reasons is the lack of awareness of gender issues by educators (Parker \& Pollock, 2013). An observable signal of this is the portraits of male scientists in classrooms. Similarly, with the names of artists: Mary Cassat and Berthe Morisot are not as familiar to the majority of readers as the names of Monet and Renoir (Parker \& Pollock, 2013). Learning material also underpins male's and female's stereotypical roles in society (UNESCO, 2008). Such education may, therefore, program future employers to favor males above females career-wise. Empirical evidence explains females' underrepresentation in management by two types of factors: work-related and familyrelated factors (Tharenou, 1999). There are strong debates in the literature regarding the care responsibilities of females. One school of thought suggests that children become an obstacle in a way of female to higher echelons (Lane, 1999; Corley, 2005; Fox, 2005; Fox \& Colletralla, 2006; Moir, 2006; Hartley \& Dobele, 2009; Carvalho \& Machado, 2010; Mavriplis et al., 2010; Ceci \& Williams, 2011; Veliz, 2019). Other evidence shows that having children may indicate women's responsibility and maturity to become senior staff (White et al 2011; White \& Bagilhole, 2013). Meanwhile, some studies did not find a gender difference in career advancement (Giuliano et al, 2005).

As education plays a vital role in determining the gender awareness of future generations, university hierarchy may also influence students' 
vision of career opportunities with respect to gender. To explore the role of gender in career progression in education, Westminster International University in Tashkent (WIUT) was chosen as a subject of study. The case of WIUT is unique as it has management practices that replicate the values and principles of the most developed countries in Uzbekistan, which is a male-dominated society (Welter et al., 2017). For example, both genders are equally welcome in recruitment and selection processes. WIUT different views might influence career advancement making it unlike others in the country.

Predominantly, the research is vital for the university management to learn whether gender equality in career advancement is predetermined by family-related factors (marital status, children) or work-related factors (qualification, work experience). The quantitative data analysis will reveal the factors contributing to career advancement. Openended questions will help university management consider the employee's concerns for further development and improvement of the university's prosperity. Furthermore, relevant commentaries might trigger the change(s) in the present job requirement in different positions.

\section{Research question}

Are there gender differences in career advancement? The case of Westminster International University in Tashkent (WIUT).

\section{Research objectives}

- To explore key career progression factors associated with career advancement

- To investigate gender equity in career advancement controlling for work-related and family-related factors

\section{LITERATURE REVIEW}

Scholars around the world are concerned with gender inequality in career progression. Gender equality at work is unfeasible due to cultural beliefs regarding the domination of men over women in some countries (Ridgeway, 2014). A large scale across-firm promotion study in Germany and Finland showed the gap in wage and exposure to first promotion between males and females, which decreases with subsequent career advancements (Cassidy et al, 2016). A study conducted at higher education institutions evidenced that being a woman is not positively associated with a managerial position (Veliz, 2019).

Gender difference in career advancement is the case to study in Central Asian countries. The research documented Uzbek females' resistance to accept that 'our social enactments of gender are not biologically ordained but are culturally and temporally specific, and can change' (Kamp 2009, p.2).

The cliché about men's biological supremacy could have generated a patriarchal society in Uzbekistan. In traditional households, the male is responsible for family provisions while the female is in charge of child-rearing (Welter et al., 2017). During the Soviet Union era, few women left home for work (Millier \& Bellamy, 2014). The females' labor force participation rate decreased by $6 \%$ from $54 \%$ in 2000 to $48 \%$ in 2019 , while males' contribution remained stable for 19 years from $75.93 \%$ to $75.01 \%$ (The World Bank, 2021). The discrepancy between women's and men's labor force participation rate has grown throughout the years. The data from a neighboring country, Kazakhstan, suggest that a female higher education representative gets 7\% less salary than a male does (Tastanbekova, 2020). This tendency demonstrates that men's superiority in the family is reflected in employment. Applying Hofstede's cultural dimensions attributes, Uzbekistan can be classified as a masculine society in which men are characterized as 'assertive and tough', while women are presumed to be 'tender and modest' (Hofstede, 1991, p. 120). Thus, the male is expected to be more competent than the female at work (Ridgeway, 2014). Hence, cultural norms can be considered as the first factor explaining gender disparity in career advancement as females may self-select themselves out of managerial positions to prefer male managers instead.

Earlier studies claim that marriage and children are negatively associated with female career advancement (Fu \& Shaffer, 2001; Kirchmeyer, 2002; Tharenou, 2005; Guillaume \& Pochic, 2009). Although a recent nation-wide US 
study (4712 women) documented that careeroriented females (49\%) replied they intend to have babies; their counterparts, careerindifferent females (17\%) of 25-45 years old, did not agree on pregnancy planning importance (Simoni et al, 2017). Many research-focused educational institutions are not family-friendly. The academic staff is expected to publish articles; obtaining grants is of the top priority, conflicting with family life (Veliz, 2019). But there is no proof that women without children are more successful in their careers; thus, women's marital status and children do not affect job performance (Caprile et al., 2012). Conversely, females with children may indicate maturity and readiness to be represented in a senior position (White et al, 2011). Cinar and Kose (2018), in their research conducted in Turkey, found that marriage is positively associated with a higher status of empowerment. Notwithstanding, females are more likely to fail in work-life balance and choose only to work or enjoy family life (Hyman \& Summers, 2004; Kelly et al., 2011; Al-Asfour et al, 2017; Cinar\&Cinar, 2018). South African research shows that even though women entrepreneurs might restrict working hours to avoid conflict between work and family, their motivation to grow the business remains high (Meyer and Keyser, 2019).

In Asian countries, like Uzbekistan, if a female is employed, she is still responsible for housekeeping. This can be identified as the second job after her direct employment. As a result, many women go for part-time or low-paid jobs (Cinar \&Cinar, 2019). For some women, housekeeping is direct labor, while the job is becoming less important, leading to lower aspiration levels (Al-Asfour et al, 2017; Cinar and Kose, 2018). Meanwhile, to move career-wise, a candidate must demonstrate aspiration, be intentional, be open to new opportunities, and be 'visible' to get a 'seat at the table of leadership' (Selzer \& Robles, 2019, p.120). Hartman \& Barber (2020) in their research found no significant difference between men and women in terms of professional self-efficacy which is the indicator of career aspiration; still, men were found to be more career-oriented.

Further investigations revealed that career breaks for family reasons have a more negative effect on a females' career rather than family devotion (Mielach, 2013). At the same time, empirical evidence suggests that any person taking career breaks, regardless of gender, faces career advancement issues (Berdahl, 2013). There is considerable evidence that due to household chores, females take time off work more often than males (Tharenou, 2005). Official paid maternity leave in Uzbekistan amounts to 2 years with an opportunity to extend it up to 3 years (Labour Code of the Republic of Uzbekistan, 2015). In contrast, ordinary maternity leave in the United Kingdom is 26 weeks, which is half a year; a mother can also take additional 26 weeks (The National Archives, 2015). The research shows that a career break of more than a year may be sufficient for required skills loss and can be a reason for career growth slowdown (Berdahl, 2013). The World Bank (n.d.) forecasts that the child dependency ratio is expected to fall by 20 percent from 2010 to 2050. This may indicate that children will not hinder a female's career anymore.

The next factor affecting career advancement is work experience. The literature reveals the gap between males and females in career advancement after controlling for job tenure (Weisshaar, 2017). Women entrepreneurs selfreported the necessity of experience along with education to build a career (Welsh, et al., 2016). Meyer (2020) study concluded that after three years of self-employed experience, motivation shifts from external to internal.

Gender discrimination is the next reason for a gender difference in career advancement.

Gelfand et al (2005) defined gender discrimination as an unequal treatment based on inadequate criteria (such as gender), which simultaneously serves as a barrier for candidate selection, promotion, professional training, and development. Al-Asfour et al.'s (2017) research found out that Saudi males do not communicate to Saudi females due to cultural background which prevents female colleagues from unleashing their potential to subsequently move a career ladder. A survey in Turkey stressed the necessity to educate men of how to treat women both at workplace and generally (Cinar \& Cinar, 2019). Recent research suggests that women may be intentionally put by management to 'the pathways that do not lead to senior positions'which is synonymized to a 'glass cliff 
'(Morley, 2014, p.124). A woman's success at work is defined as luck; a woman's failure is tied to the lack of knowledge and experience. Conversely, if a man exceeds the employer's expectations, his talent is praised but man's failure is commented as bad luck (Macarie \& Moldovian, 2012). Discriminatory interpretation of success and failure can prevent females from career progression.

Gender discrimination is metaphorically termed as a 'glass ceiling effect'to illustrate invisible blocks restricting women's entry into 'higher echelons'(Haslam \& Ryan, 2008, p.530). A 'glass ceiling'study shows that it does not explain only women under-representation in management but also limits women's opportunities for career progression (Cotter et al., 2001; Gupta, 2018; Sharma\& Kaur, 2019). Later research opposes the notion of the glass ceiling effect, since the empirical evidence showed higher advancement rates for females rather than males (Petersen \& Saporta, 2004).

Educational background is another predictor of gender inequality in management.

Teaching has always been female dominated; however, the under-representation of women at the executive level in the education arena has been well documented and is considered to be an international phenomenon (Acker, 1992; Bacchi, 1993; Doyle \& Hind, 1998; White, 2011; Selzer and Robles, 2019). The situation is paradoxical: first, the society labels all professions into male and female ones but afterward, men invade women's territory to seize the reins. It can happen, as an educator is a woman's job but a man's career(Limerick, 1999). While women climb the organizational ladder in femaledominated fields, men go to the top by 'glass elevator': once a man occupies a lower position, there is a mentor of the same gender who supervises the man (Williams, 1992; Hartman \& Barber, 2020). The study conducted since 1996 across the continents in 48 female-dominated professions, e.g., preschool teacher (proportional rate 0.94$)$, nurses (0.91), receptionist (0.81), males on average are reported to have exactly the same callback rate as female do (Birkelund, 2019). A four-year study in Ontario, Canada found a huge asymmetry in promotion to full professorship in favour of men (Millar\&Barker, 2010). A similar study in Turkey indicated that men are twice as much promoted as women are in nursing (Turkmen \& Eskin Bacaksiz, 2021). The data can bring to the idea that while researchers are trying to grasp the attention of the world society to inequality in male-dominated areas, which cannot be possible in the contemporary world; few attempts were made to explore a woman's territory.

Another research finding was that a subject area per se is not a predictor of a female's growth in non-STEM (Social and behavioral sciences, humanities, business, art/design) disciplines (O'Connor et al., 2012). In fact, the reason is female over-representation in non-STEM disciplines.

Discipline allocation according to gender is still the case in Uzbekistan. More than two-thirds of females make their study choice in favor of nonSTEM disciplines while males outnumber females in STEM disciplines (Science, Technology, Engineering, and Mathematics) where females are represented by less than onethird (UNESCO, 2008). Regardless of the discipline choice, males' participation in tertiary education prevails over the females' (UN, 2010; WFUNA, 2015). Uzbekistan-wide statistics (2019) suggests that the Gender Parity Index of women enrolled in higher education equals 0.83 , which means disparity advantaging males over females (World Bank, 2020). Being guided by the stigma that marriage will play a dominant role in the lives of their daughters, some parents underestimate the importance of education. Graduation from universities in other countries is even far more seldom, as parents are not eager to allow their daughters to live 'away from home', which ultimately leads to the skewed representation of international education holders in favor of males (Somach, 2010, p.58). In the meantime, education received abroad is appreciated for the candidates applying for international organizations. Thus, females are limited in a job search.

The next factor is the degree. A degree defines upward mobility across a career ladder ( $O^{\prime}$ Connor et al., 2012). Education level of daughters in Asian families (e.g. Turkey) rings alarm bells (Cinar \& Cinar, 2019); while higher education is positively associated with women empowerment (Cinar\& Kose, 2018). 
In South African woman entrepreneurship research, the findings suggest a high correlation between business training and the willingness to grow professionally, although those going through previous entrepreneurial training demonstrated lower external motivation (Meyer\& Hamilton, 2020).

Research in academia showed that full professorship is a prerequisite for a managerial position (Carvalho \& White, 2013). Simultaneously a degree may predefine an entering position of a candidate. Being a professor increases the chances of starting work in a managerial position. However, the statistics demonstrates that only one out of five full professors is female (Bagihole \& White, 2013). Men start with higher entering positions, which makes it difficult to avoid gender hierarchy in upper levels (Tharenou, 1997; Betts, 2011; Kauhanen \& Napari, 2015). According to the WIUT job description, the full professorship is not a precondition for administrative career advancement (Human Resources, 2015). As per statistics only $13.35 \%$ of females completed bachelor's degrees in Uzbekistan as opposed to $18.35 \%$ for males ("Uzbekistan | Gender | World Bank Development Indicators", 2021).

Given the mixed literature findings regarding gender equity in career advancement and the limited number of studies within Uzbekistan, the research needs to be conducted. Furthermore, little empirical evidence was found in academia. The goal of this paper is to contribute to the literature by analyzing data collected in a unique university, which is blending the traditions of British education with the cultural heritage of Uzbekistan.

\section{RESEARCH METHODOLOGY}

The research was inspired by the study of LaPierre and Zimmerman (2012) conducted in the USA in healthcare. The methodology is replicated though with a smaller sample in academia. T-test was utilized to compare male and female academic representatives on a number of variables as a part of initial analysis. To investigate gender equity in career advancement logistic regression was run controlling for work related and family related factors. 'Advanced' current position in the university was utilized as a dependent variable.
All the others are independent variables. Each of these variables was a dichotomous variable (1=yes; $0=$ otherwise). The main independent variable was gender ( $1=$ female; $0=$ male). Marital status was a dummy variable ( $1=$ married; $0=$ otherwise). The next dummy variable is children ( $1=$ yes; $0=$ otherwise).

Data for the research were obtained from Westminster International University in Tashkent since it was easier to gain an access utilizing a convenience (haphazard) sampling technique. The sample size is 76 academic staff colleagues out of 118 (total population) took part in a survey.

A deductive approach is used in the research quantitative methods. Two open-ended questions in a questionnaire generate participants' opinions, views and experience.

The research aims at exploring phenomenology within the organization, so the strategy is a case study (Robson, 2002). Simultaneously a case study has a limitation that the results are not generalisable.

The research tool is a questionnaire, which is based on the factors taken from the literature review (see Appendix A for a questionnaire sample). In contrast to an interview, questionnaire utilisation lessens the observer bias risks which will be discussed later.

The response rate is $98.4 \%$ for a hard copy questionnaire and $64 \%$ for an online questionnaire. $88.4 \%$ is an overall rate.

\section{Research Ethics}

Prior to the survey the respondents were informed about the topic and the purpose of the study. The participation in the study was voluntary, thus the questionnaires were distributed only when the potential respondents agreed to participate in the research. Besides an oral notification, data security and confidentiality terms were stipulated on the questionnaire.

\section{Time horizons}

The research is 'snapshot' not taking more than one year, and consequently does not require a longitudinal study.

Validity 
To ensure that questions are not offensive or/and leading, the questionnaire was piloted and some amendments were introduced afterwards.

A lecturer's office (consisted of six people) was chosen randomly, and the colleagues were asked to participate in a piloting version to make all the commentaries on any constituent of the questionnaire. Only after that, the study was continued with a larger sampling.

\section{Reliability}

As the researcher conducted the study among her colleagues, there was a possible risk of unreliable answers as some of the participants might want to hide personal information or hesitate to explicitly state their plans due to probable conflict of interests. To address this issue, prior to the survey, it was indicated that once the questionnaire is filled in, a special box will be provided to deposit the form.

The respondents were approached individually; personal request might have been misinterpreted as asking to do a favour and the sense of collegiality may question reliability.

The target audience may change with a possible turnover of staff; additionally, building on a voluntary basis, next time the research is carried out other people may participate in it what might affect the results accordingly.

Robson (2002) says that there are possible threats besides those mentioned above, e.g. a participant error which is caused by the influence of such external variables as a day of the week, time of the day, mood. Participant error is possible in a current study due to the following reasons: proposal feedback was received later than it was planned. At the time the questionnaire was approved with the Research Ethics committee the academic staff of WIUT was busy with marking the examination and coursework papers, completing Module Leaders/Course Leaders etc. reports, which could lead to unreliable answers to the questions.

Alternatively, there is a possibility of a participant bias who may suppose that the respondents' answers will be disclosed to the university management. The terms of confidentiality were stated, though there is still a risk that some participants might write what they think their managers want to read.

Similarly, there is a potential of an observer error which is usually based on question inconsistency and automatically excluded using questionnaires. As well as assuring research validity, the piloting was also run to exclude the probability of an observer error.

Finally, an observer bias may result in misinterpreting the replies. Here the probability is low as the questions are straightforward and the answers to them are designed the way that participants need to tick an option which is more appropriate for them.

However, an observer bias might be the case in qualitative data analysis of open-ended questions. The observer might not understand correctly what the respondent meant and misinterpret it consequently. The issue may be eliminated if the respondent was approached again to clarify incomprehensible answers which is impossible with anonymous questionnaires. To prevent a potential problem interpreting the data, the respondents might be asked to state their names which in its turn increases the amount of unreliable answers. So, before running a questionnaire with open ended questions, there is a choice between reliability and a possible observer bias interpreting the results. The present study employed the latter. Yet, it is acknowledged that the data might be interpreted differently by other third parties.

\section{Generalisability}

The results of the research and subsequent conclusions are not going to be generalized as the study is conducted within one organization, thus may not be the case in other institutions of Uzbekistan.

\section{RESULTS}

The data obtained were used to compare male and female employees on several variables. To see whether the difference is significant the $t-$ test was used. Logistic regression is provided in Table 1.

Consistent with a gender distribution a little more than half of the sample are females (53\%). 
As it can be observed in Figure 1 below, the majority of the total sample are married or cohabiting (58\%). As for females, $45 \%$ are married as opposed to $72 \%$ of married males.

Figure 1. Marital status

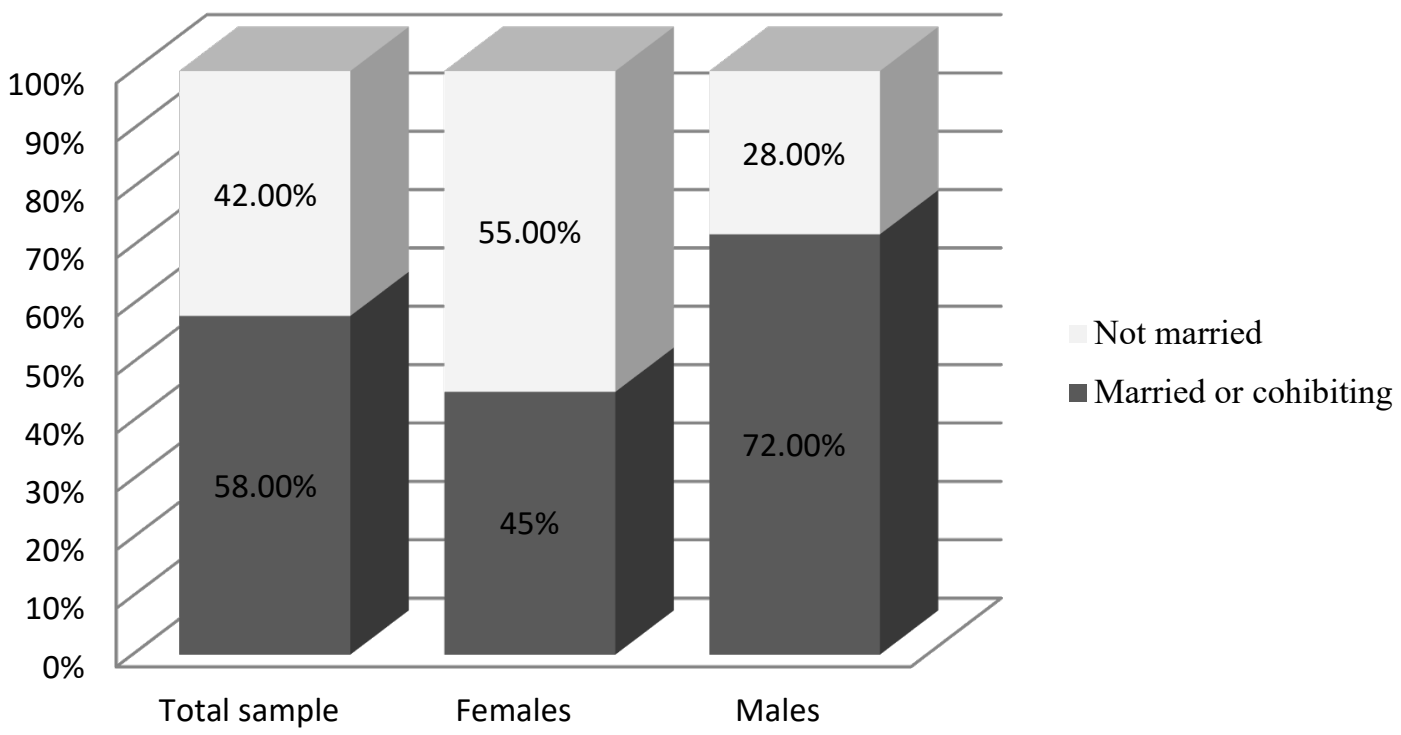

Source: Developed by the author

According to Figure 2, half of the respondents in the total sample do not have children. Within half, the difference between males and females

Figure 2. Having children

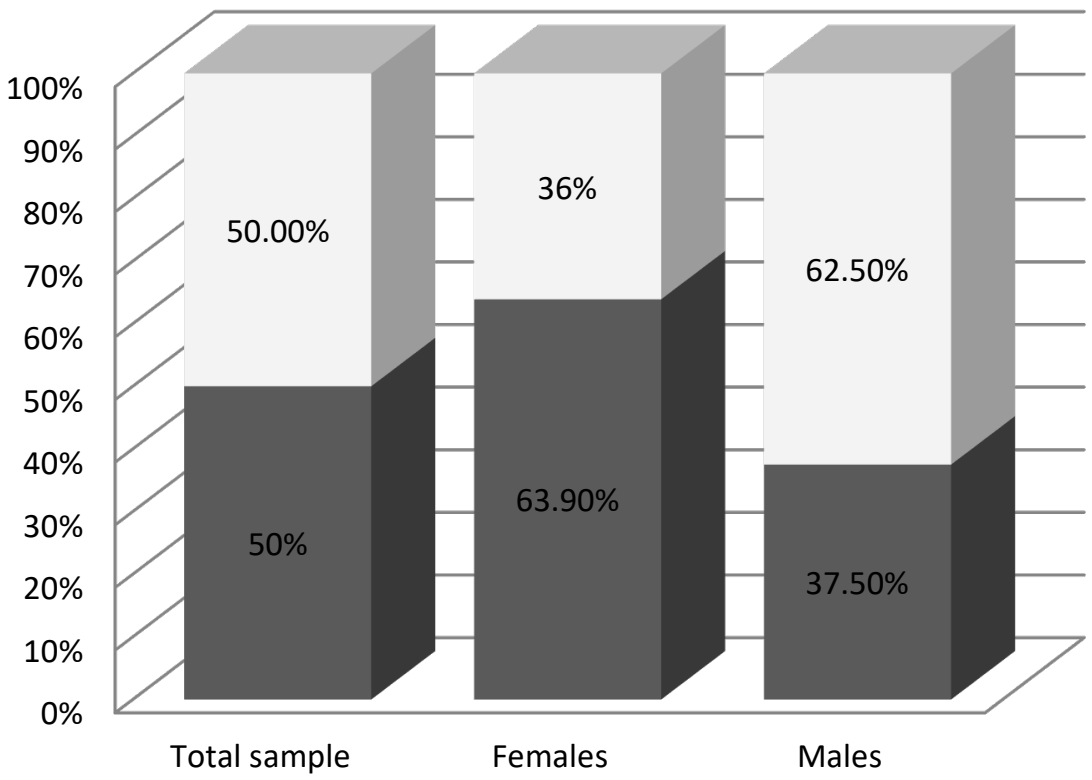

having children is significant (63.9\% versus $37.5 \%$ accordingly).
Have children

- No children

Source: Developed by the author 
The next variable to examine is the level of qualification. As it can be observed in Figure $3,63.2 \%$ of the surveyed academics are masters, which is three times the number of bachelors (21.05\%) and four times as many as doctors (15.8\%).

Figure 3. The highest education degree

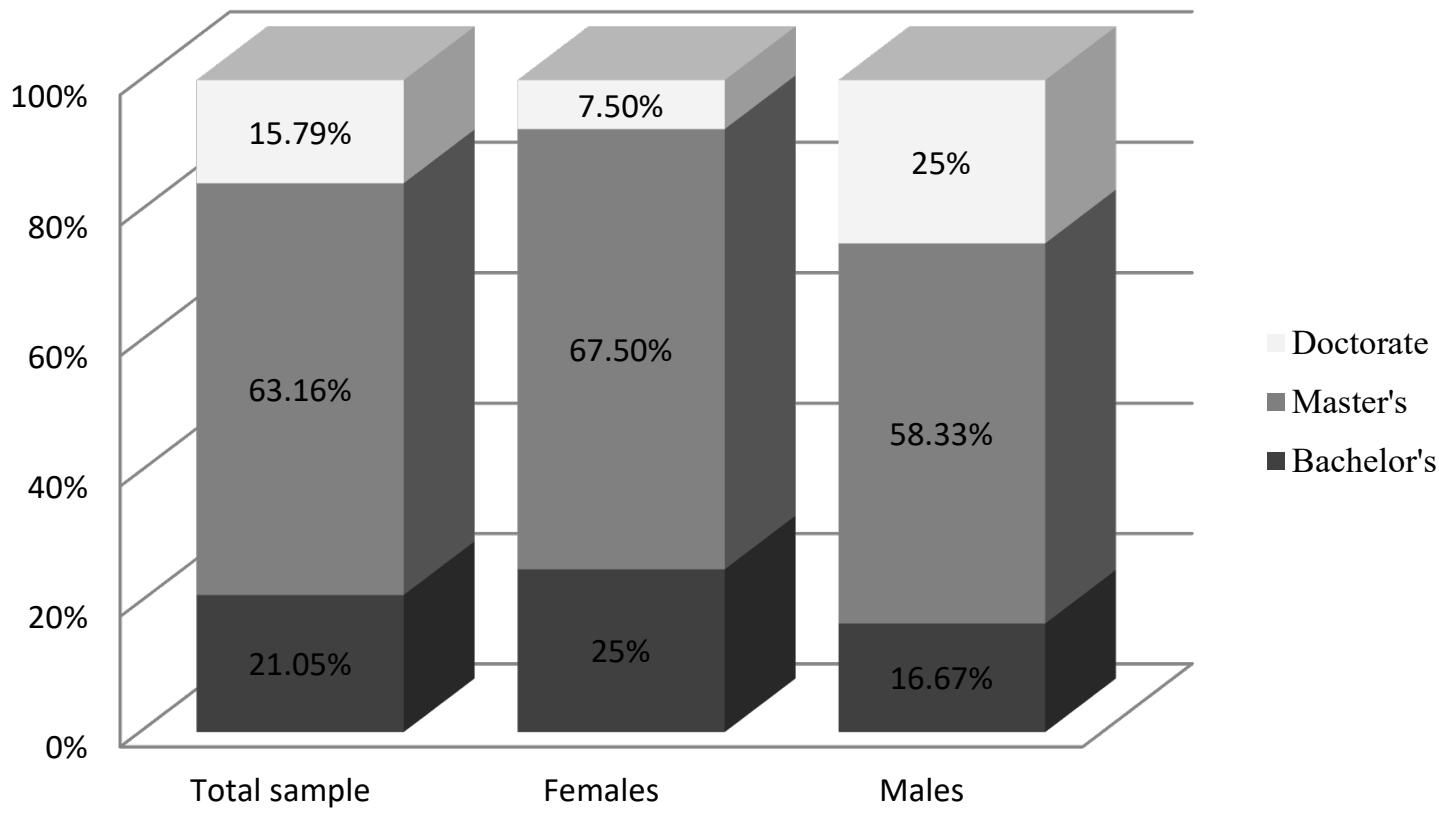

Source: Developed by the author

The work experience statistics demonstrate similar results. Even looking at different time horizons, the difference between males and females is not significant.

Looking at the next factor, consistent with Figure 4 below, $34.2 \%$ of respondents are from the 'English Language and Personal Development' subject area. $27.64 \%$ work for 'Economics' and 'Finance' subject areas. A slightly lower percentage is shared by 'Business' representatives (21.05). 7.9\% is taken by 'Commercial Law' and 9.22\% 'Business Information Systems (BIS)'.

Half of the females (50\%) work in the 'English language and Personal Development' area as opposed to $13.89 \%$ of males, the difference is statistically significant. $20.5 \%$ of the surveyed females are from 'Business', almost the same
Gender-wise, the results show asymmetry: males have an obviously larger proportion of Ph.D., which is the quarter of the male respondents (25\%), while female Ph.D. holders account for $7.5 \%$. 
Figure 4. Subject area

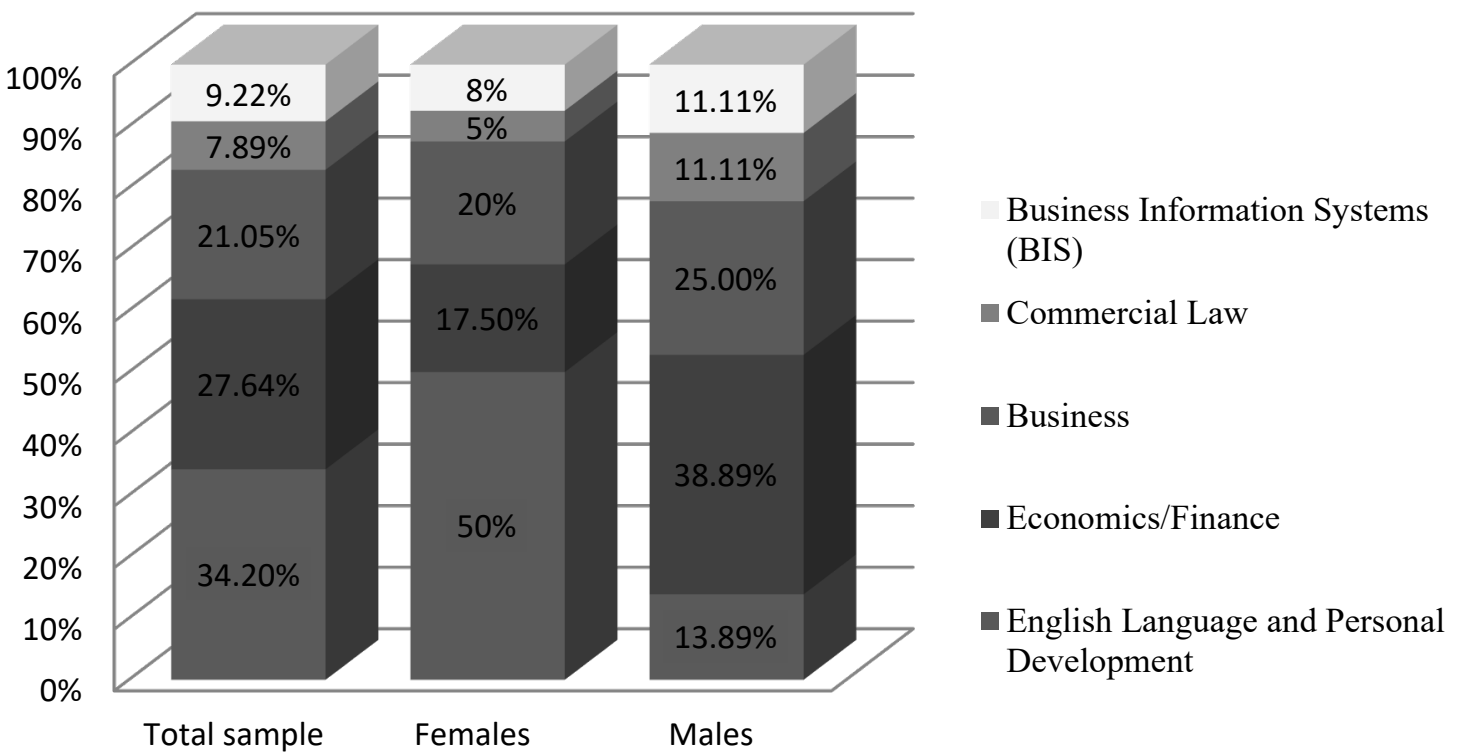

Source: Developed by the author

As Figure 5 reports, currently, Lecturers constitute the major fort (73.7\%) of the academic staff. Course Leaders amount to $10.5 \%$; Subject Area Leaders are $5.3 \%$ of the total; Deputy Deans make 5.3\%; Deans 2.6\%; and Deputy Rectors account for $2.6 \%$.
The difference in percentage between female (83\%) and male Lecturers (64\%) is not significant. Other positions do not show a significant difference.

Figure 5. Current position

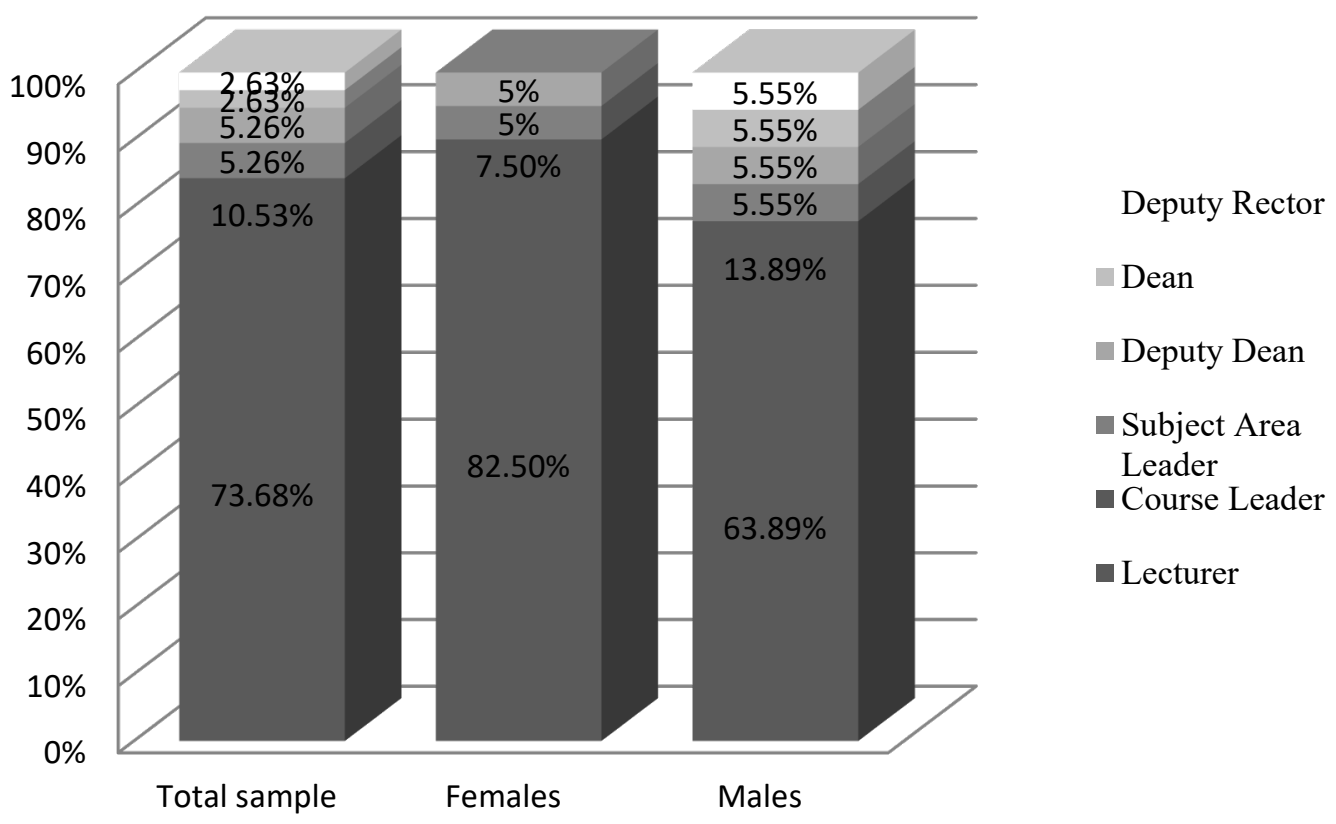

Source: Developed by the author 
The first: the respondents feel discriminated against both gender and experience; the second group: because they do not possess sufficient experience; and the third: because of gender. No significant difference between the two samples' replies is observed.

Figure 6. Feeling discriminated against in obtaining a higher position

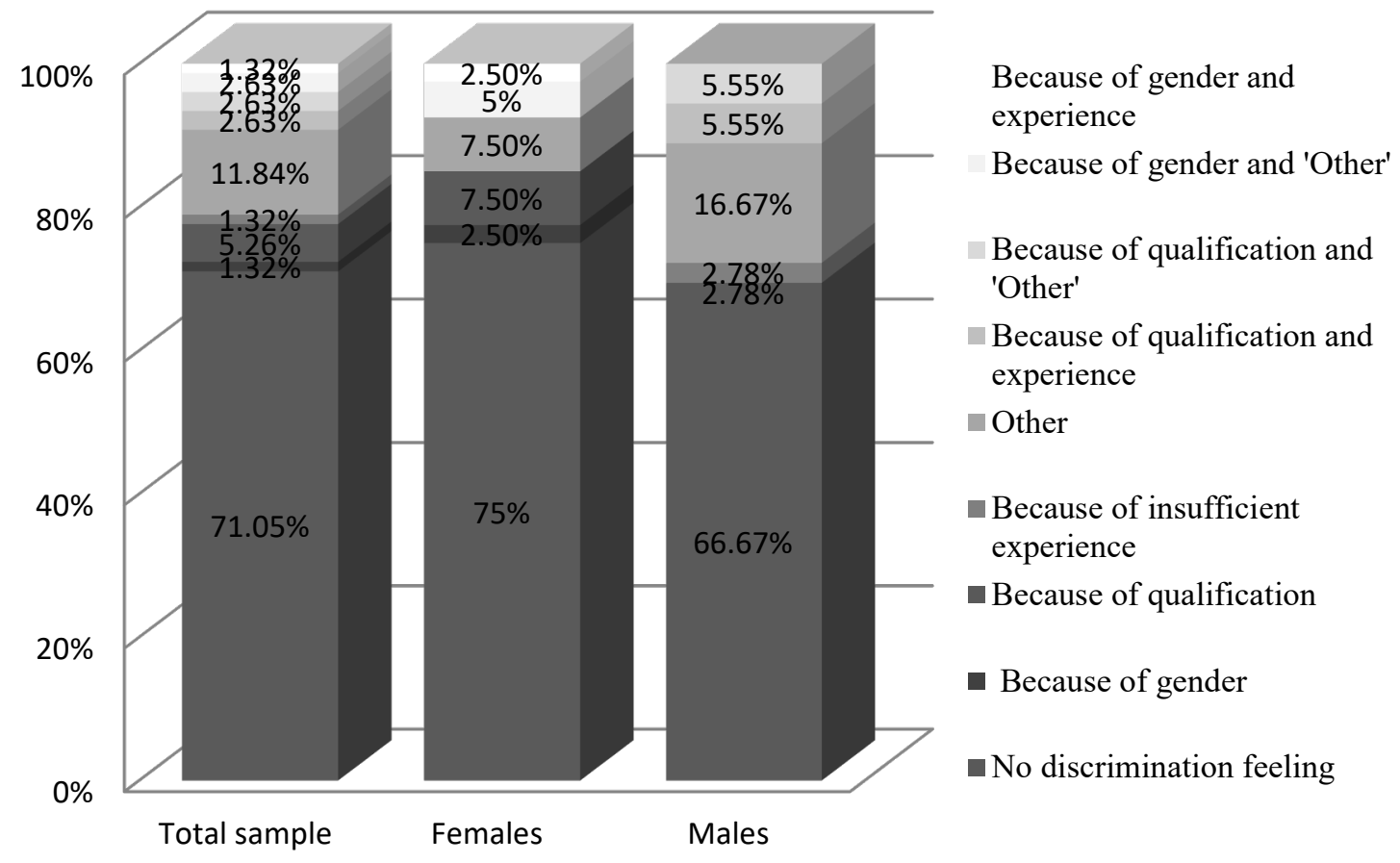

Source: Developed by the author

Figure 7. Gender preferences in management

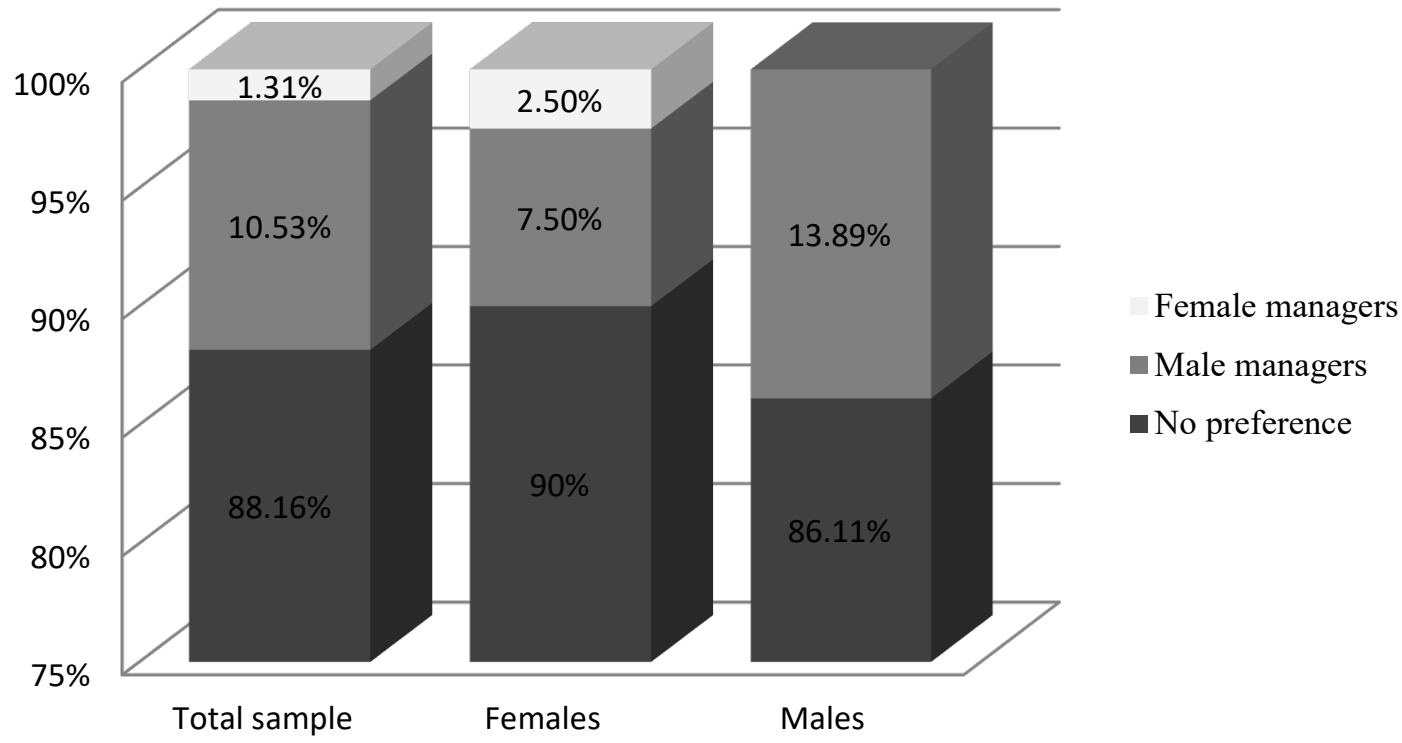

Source: Developed by the author 
Figure 7 demonstrates the next factor employees' preferences towards a gender balance in management:

The majority of the surveyed academics (88.2\%) are believed not to be biased and having no gender preferences in management. However, $10.5 \%$ prefer to have male managers; and the minority (1.3\%) want to see female managers.

Female employees in a great majority do not have any preferences. However, 7.5\% consider their male counterparts better managers; while $2.5 \%$ favor female managers.

Males are revealed to be more conservative not preferring the opposite gender as managers: $86.1 \%$ stand for no preference, $13.9 \%$ support their fellows.

To summarise, the initial analysis of the sample by gender showed that the following variables are statistically significant: marital status, having children, obtaining a Ph.D. degree, being in subject areas such as English language and Personal Development, Economics and Finance; taking a career break for family reasons. To see whether these factors are career advancement drivers, a logistic regression needs to be run.

Logistic regression in Table 1 tested two models: in Model 1 career advancement was controlled for work-related factors such as education, work experience, discrimination feeling, gender preferences in management, subject area, and an entering position. In Model 2 family-related data were added, such as marital status, having children, and taking a career break for family reasons.

As reported in Table 1 neither in Model 1 nor in Model 2 female's career advancement was found significantly different from males. In Model 1 the respondents with a Ph.D. have statistically significant $(\mathrm{p}<0.01)$ association with career progression with no statistically significant gender difference. The result is consistent with the initial t-test analysis, which explains the importance of a Ph.D. as male lecturers hold a Ph.D. more than three times comparing female lecturers. However, the significance is not sufficient to be the reason for gender inequity in career growth opportunities.
Being biased towards management gender is negatively associated with career advancement. Those who prefer male managers are significantly less likely associated with career advancement $(\mathrm{p}<0.001)$ than those who prefer females.

The results from the respondents with Economics/Finance background are negatively associated with career progression in contrast to the Business area $(p<0.01)$. The result is consistent with the t-test report that was presented in a descriptive part of the analysis. However, this factor does not cause a statistically significant gap between genders career-wise.

The sample having an English language background is less likely to be advanced as opposed to the holders of Business education $(\mathrm{p}<0.01)$. English language subject area was also found significant in the initial analysis. However, along with Economics/Finance background, this difference was not reflected in the significant disparity between genders in career progression.

Even after adding family-related factors such as marriage and children (Model 2), the difference between males and females in career advancement is still not statistically significant. The factors that showed statistical significance in association with career advancement are still the same. In Model 2 having a Ph.D. is a better career advancement predictor than a bachelor's degree $(p<0.05)$. The preference for male management is reflected in lower chances of being advanced $(\mathrm{p}<0.001)$. Economics/Finance background holders are less likely to be advanced than Business area representatives $(\mathrm{p}<0.05)$. English language background also demonstrated similar results $(\mathrm{p}<0.05)$.

The analysis revealed several factors that are recommended to be taken into account by future investigations of this topic: 'favoritism' (in the meaning of giving preferences for career advancement to those who are on good terms with management); 'age' of the employees. Other categories were formed by single contributions. 
Table 1. Logistic regression

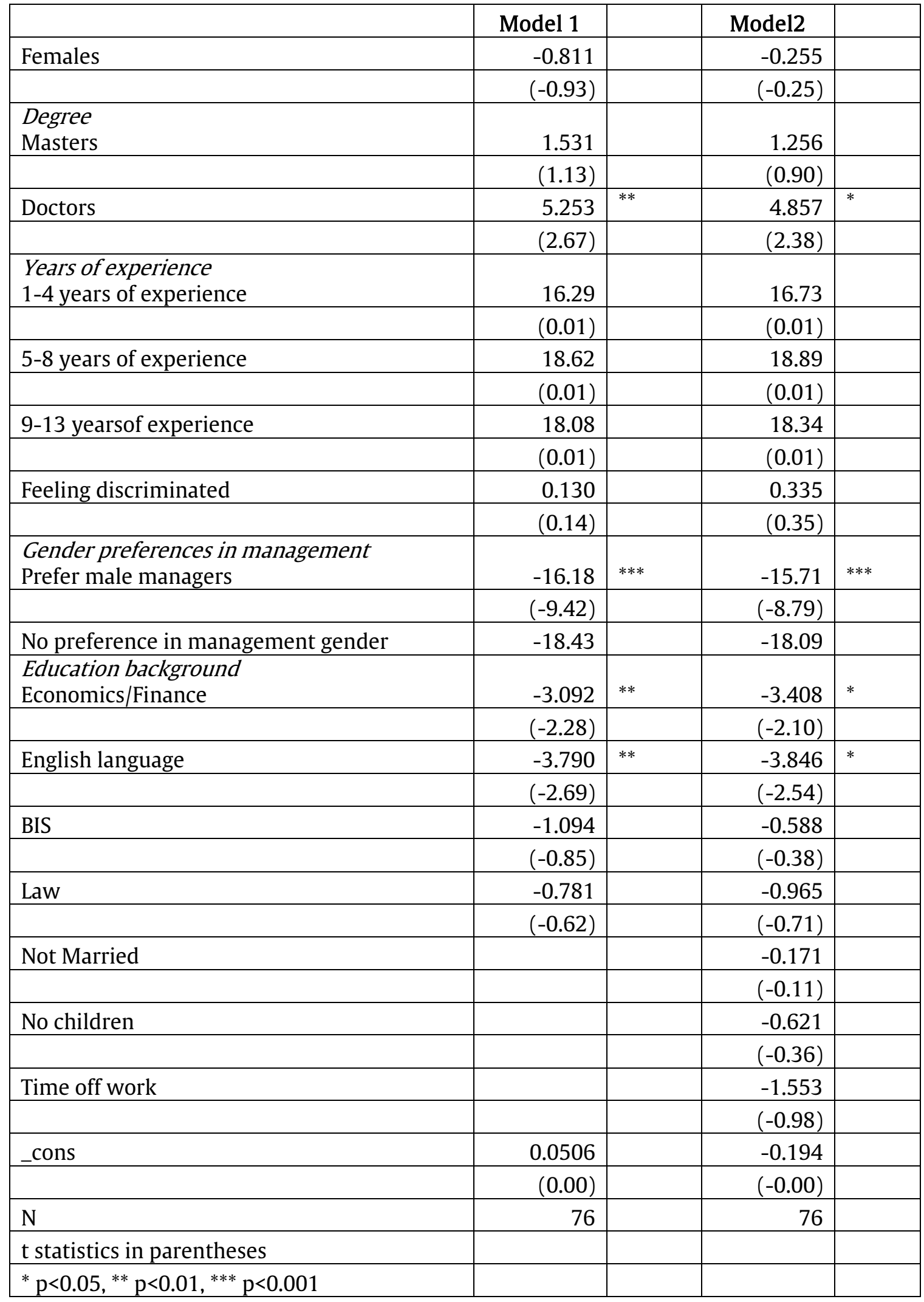

Source: Developed by the author 
Among the other questions, there was an invitation to commentaries.

The most frequent comment from the respondents is favoritism. The respondents did not specify whether the preferences are given based on gender. Relying on the data given by the respondents, favoritism exists at WIUT but whether it advantages only males or females, or both genders is still not known. The topic is very sensitive and those who have evidence regarding such practices most probably will not report it, making the results of such investigation not reliable. At the same time, when respondents point toward the issue, they are usually in the minority, and data obtained are again considered inadequate to make any conclusions. Only assumptions can be made that can serve as a prompt for further study.

As for age, in WIUT case it might not show significance as the organization is quite young; furthermore, it is recruiting mostly young candidates (graduates). However, if the research is done in local universities, this variable may show the results different from WIUT's.

\section{DISCUSSION}

Going back to the objectives set, in this part, the link between the literature review and the results will be established.

The first variable is the employee education degree. It was discussed in the literature review that a doctoral degree (O'Connor et al., 2012) is strongly associated with career advancement. Model 1 test shows that having a doctorate degree contributes to the career advancement of both gender representatives. Furthermore, running a regression with family-related factors (Model 2), a doctorate degree also demonstrates significance. So, the WIUT case result is consistent with O'Connor et al.'s study (2012).

The second variable is work experience at WIUT. The number of years is used as a proxy for career advancement chances. The literature said that males progress faster. There was also suggested that after 4 years of service, a female does not wish to have career advancement (Stone, 2007). Most probably it happens due to family obligations which take a major part in females' life, especially in some Asian countries. So, the larger the number of years employed, the longer a person stays in one position. Contradicting the expectations in the literature, the length of work experience at WIUT is not associated with career advancement neither for males nor females.

The next variable to consider is discrimination suggested by Gelfand et al (2005); Al-Asfour et al (2017); Cinar \& Cinar (2019). There are a lot of debates in the literature regarding females' discrimination in obtaining a higher position, especially in male-dominated professions. However, the research is done in education and teaching is considered as a female-dominated area; still, there is an assumption that females are not well represented in education management due to 'glass elevator' that works only for males (Williams, 1992; Casini, 2016; Turkmen \& Eskin Bacaksiz, 2021).

Discrimination does not show any significance and the literature finding is not proved for the WIUT case.

Along with discrimination, there is a problem with gender-bias. There are intensive discussions in the literature regarding the Central Asian region's peculiarities. It was assumed that women do not strive for a managerial position as they prioritize family instead (Kamp, 2009). Furthermore, there are commonly spread opinions that males are stronger than females (Ridgeway, 2001). The question of the preference towards gender in management was included to address the bias issue. The regression analysis found a negative association between employee bias and career advancement. However, it is not strong enough to bring a significant gender difference in professional growth. As descriptive analysis shows, there is not a high rate of selfreport bias. Considering that self-report bias does not guarantee bias absence, there is a recommendation for further researchers to include in their investigation special tests that detect unconscious bias of the respondents. The link to one of such tests is provided in parentheses

(https://implicit.harvard.edu/implicit/selectates t.html). Due to time limitations, the research was not able to employ it.

The following variable in the regression is a subject area. It was suggested that females in humanities are more likely to have career advancement than in engineering and 
mathematics (Tharenou, 1999). Initial analysis also shows that females are statistically more presented in the English language area rather than Business Information Systems, for example.

The regression result demonstrates a statistically significant association between a subject area and career advancement in the example of the English language and Economics/ Finance areas. However, the negative association is found for both males and females with no statistically significant difference.

The last variable in work-related factors is an entering position. According to Tharenou (1997), usually males commence their careers with a higher position than females. Thus, the chances of career advancement are not equal. The proportion of those who were hired in the above Lecturer position is rather small so the regression does not show any result. The research declined the relationship claimed by Tharenou. It might be explained by a unique WIUT feature of recruiting graduates. It makes genders equal in starting their career from the same point. Age is also emphasized in qualitative analysis. It is advised to include this variable in further research.

The next part of the analysis will concentrate on family-related factors.

Several discussions in the literature suggest that females with husbands and children are not expected to prioritize career advancement over the family. Marital status and having children were among the questions with the purpose to observe whether Tharenou (2005), Guillaume \& Pochic (2009) were right reporting that women perceive the family as an obstacle in their way to career growth. Or if this study proves Caprile's (2012) finding that there is no correlation between having family and a career.

It was decided to put 'not married' and 'having no children' as independent variables to see if being single and childless is associated with career advancement. It was expected that adding the variables in Model 2 the indicator of females' career progression would become statistically significant. The analysis found no association between having a family and career advancement. Besides, the WIUT case revealed no association between having children and career advancement, which contradicts Tharenou (2005), Guillaume \& Pochic (2009), but is consistent with Caprile (2012).
The other factor that was tested in Model 2 along with marriage and children is a career break for family reasons. Berdahl (2013) argued that taking career breaks can negatively reflect on the career advancement of both genders. In a research sample, none of the male participants took career breaks; so, genders are not possible to contrast. Meanwhile, taking career breaks did not affect the sample in occupying a higher position. Berdahl's theory can be rejected in the WIUT case.

Based on the analysis, there are no grounds to claim that family-related factors (for instance, marriage, children, career breaks) are the obstacles to females' career growth. The workrelated factors (education degree, a subject area) are statistically significant, but they equally contribute to female and male careers revealing no statistically significant gender difference career-wise.

\section{CONCLUSIONS}

The research was aiming to find out if an international university in Uzbekistan reflects literature review trends on gender discrimination in academic career advancement. Controlling for such variables as family, children, education degree no statistically significant difference was demonstrated. Meanwhile, the qualitative part of the survey acknowledged other factors that can hinder educators from being promoted, e.g., favouritism.

\section{RESEARCH LIMITATIONS}

During the survey one of the colleagues claimed that proper confidentiality cannot be guaranteed as by stating the position, the circle of people who gave this or that answer is narrowing down. For example, if a person specifies that $s$ /he is from a particular area (Commercial Law, BIS and others) and then s/he ticks Course Leader's position, it becomes clear who the person is. This is an obvious research limitation as it could be the reason why people do not write what they want. Particularly at WIUT this problem can be lessened by writing the options of Course Leader and Subject Area Leaders in a questionnaire with a slash as according to Uzbekistan legislation they are both interpreted as a Senior Lecturer. By this, room to 
maneuver could be provided as there would be at least two people to choose from.

Also, one of the limitations is a rather small sample size, thus the results cannot be generalized Tashkent-wide or what is more ambitiously Uzbekistan-wide.

To see a big picture of gender equality in career progression, there is a need to carry out the research in a larger scale.

WIUT is a University of Westminster (London) affiliated university, which brought western corporate culture and distinguished WIUT among other local universities country-wide. For that reason, the results obtained might not be consistent with the a similar study conducted in local universities.

\section{RECOMMENDATIONS}

As the qualitative analysis of this paper suggests future explorations are recommended to consider other factors such as age and personal preferences. However, researchers should take into account that including these factors into a questionnaire will increase data sensitivity, which in turn might reduce a response rate.

Self -report bias has low reliability and does not guarantee adequate results of regression on that particular variable. So that, as it was mentioned in the analysis, future studies are suggested to implement specially designed tests to detect unconscious bias and its association with career progression.

In the process of concluding the research, it was communicated that WIUT would go through faculty restructuring, which would be reflected in job responsibilities reconsideration. There might be a lot of changes, including the candidates appointed at a particular position. So, further research is recommended to be conducted, which may end up with different results.

All in all, the current study can be considered as a stepping stone for a larger study in the future.

\section{RESEARCH IMPLICATIONS}

The study results are of practical importance for Human Resources Management teams. An understanding of what employees see as barriers for career advancement can contribute to Key Performance Indicators revisiting to create healthy environment for professional and personal development. The government might find this study useful in defining what kind of support women need to demonstrate more empowerment.

\section{REFERENCES}

Al-Asfour, A., Tlaiss, H. A., Khan, S. A., \& Rajasekar, J. (2017). Saudi women's work challenges and barriers to career advancement. Career Development International, 22(2), 184-199. doi:10.1108/cdi-11-2016-0200 [Accessed 14 July 2021]

Bagilhole, B., \& White, K., (2011). Gender, power, and management: a cross-cultural analysis of higher education.UK: MS\&E[online] Available from: $<$ http://www.palgraveconnect.com/pc/doifi nder/view/10.1057/9780230305953>

[Accessed 16 September 2014]

Bagilhole, B., \& White, K. (Eds.)., (2013). Generation and gender in academia. Basingstoke: Palgrave Macmillan.

Betts, K. (2011). Career advancement: Ten negotiation strategies for women in higher education. Academic Leadership: The Online Journal, 9(3), 3.

Birkelund, G. E., Janz, A., \& Larsen, E. N. (2019). Do males experience hiring discrimination in female-dominated occupations? An overview of field experiments since 1996. GEMM working paper, https://gemm2020. eu/wp-content/uploads/2018/12/GenderDiscrimination-a-summary-1. pdf.

BusinessDictionary.com,(2015). Convenience sampling.[online] Available from: $<$ http://www.businessdictionary.com/defini tion/convenience-sampling.html> [Accessed 23 July 2015]

Caprile, M., Addis, E., Castaño, C., Sagebiel, F., Schiebinger, L., Valles, N.,\& Roivas, S., (2012). A meta-analysis of gender and science research: synthesis report. [online] Available from: European Union <https://ec.europa.eu/research/swafs/pdf/pu b_gender_equality/meta-analysis-of- 
gender-and-science-research-synthesisreport.pdf $>$ [Accessed 22 November 2014]

Carvalho, T., White, K., \& Machado-Taylor, M., (2013). Top university managers and affirmative action. Equity, Diversity and Inclusion, 32(4), 394409.

Carvalho, T., \& Machado, M. L., (2010). Gender and shifts in higher education managerial regimes: Examples from Portugal. Australian Universities Review, 52(2), 3342.

Casini, A. (2016). Glass ceiling and glass elevator. The Wiley Blackwell Encyclopedia of Gender and Sexuality Studies, 1-2.

Cassidy, H., DeVaro, J., \& Kauhanen, A. (2016). Promotion signaling, gender, and turnover: New theory and evidence. Journal of Economic Behavior \& Organization, 126, 140-166.

Ceci, S., \& Williams, W., (2011). Understanding current causes of women's underrepresentation in science. PNAS, 108(8), 31573162.

Cinar, K., \& Kose, T. (2018). The determinants of women's empowerment in Turkey: A multilevel analysis. South European Society and Politics, 23(3), 365-386.

Cinar, K., \& Ugur-Cinar, M. (2018). What the City Has to Offer: Urbanization and Women's Empowerment in Turkey. Politics \& Gender, 14(2), 235-263.

Corley, E., (2005). How do career strategies, gender, and work environment affect faculty productivity levels in university-based science centers? Review of Policy Research, 22(5),637655.

Cotter, D.A., Hermsen, J.M., Ovadia, S. \& Vanneman, R., (2001).The Glass Ceiling Effect, Social Forces, 80,(2), 655-682. [online] Available from: <http://www.vanneman.umd.edu/papers/co tterhov01.pdf> [Accessed 02 February 2015]

Doyle, C., \& Hind, P. (1998). Occupational stress, burnout and job status in female academics. Gender, work \& organization, 5(2), 67-82.

Fox, M., (2005). Gender, family characteristics, and publication productivity among scientists.Social Studies of Science, 35(1), 131150.
Fox, M., \& Colletralla, C., (2006). Participation, performance, and advancement of women in academic science and engineering: What is at issue and why. Journal of Technology Transfer, 31, 377386.

Fu, C. K., \& Shaffer, M. A. (2001). The tug of work and family: Direct and indirect domainspecific determinants of work-family conflict. Personnel review.

Gelfand, M. J., Nishii, L. H., Raver, J., Schneider, B., Dipboye, R., \& Colella, A. (2005). Discrimination at work: The psychological and organizational bases. The Organizational Frontiers Series, 89-116.

Giuliano, L., Levine D., \& Leonard J., ( 2005). Do Race, Gender, and Age Differences Affect Manager-Employee Relations? An Analysis of Quits, Dismissals, and Promotions at a Large Retail Firm. Center for Responsible Business, University of California, Berkeley.

Gupta, S. (2018). Glass ceiling in 21st century: Women in management. International journal of management studies, 3(5), 83-93.

Hartley, N., \& Dobele, A., (2009). Feather in the nest: Establishing a supportive environment for women researchers. The Australian Educational Researcher, 36(1), 4358.

Hartman, R.L. and Barber, E.G. (2020), "Women in the workforce: The effect of gender on occupational self-efficacy, work engagement and career aspirations", Gender in Management, Vol. 35 No. 1, pp. 92-118. https://doi.org/10.1108/GM-04-2019-0062 [Accessed 14 July 2021]

Haslam, S.A. \& Ryan, M.K.,(2008). The Road to the Glass Cliff: Differences in the Perceived Suitability of Men and Women for Leadership Positions in Succeeding and Failing Organizations. The Leadership Quarterly, 19(5), 530-546. [online] Available from: <http://www.sciencedirect.com/science/arti cle/pii/S1048984308000957> [Accessed 01 November 2014]

Herzberg, F., Mausner, B. \& Snyderman, B. B., (1959). The motivation to work. New York: John Wiley \& Sons. [online] Available from: $<$ http://pareonline.net/getvn.asp? $\mathrm{v}=5 \& \mathrm{n}=11$ $>$ [Accessed 01 February 2015] 
Hofstede, G., (1991). Cultures and Organizations: Software of the Mind, McGraw-Hill, New York, NY.[online] Available from: <http://www.idemployee.id.tue.nl/g.w.m.ra uterberg/lecturenotes/DG000\%20SCA/Cultur es\%20and\%200rganizations.Hofstede.EBS.pd f $>$ [Accessed 27 October 2014]

Hultin M., (2003). Some Take the Glass Escalator, Some Hit the Glass Ceiling? Career Consequences of Occupational Sex Segregation. Work and Occupations. .[online] Available from:<http://www.researchgate.net/publica tion/249690452_Some_Take_the_Glass_Esc alator_Some_Hit_the_Glass_Ceiling_Career_ Consequences_of_Occupational_Sex_Segreg ation> [Accessed 03 October 2014]

Hyman, J., \& Summers, J., (2004). Lacking Balance? Work-life employment practices in the modern economy. Personnel Review, 33(4), 418-429. [online] Available from: <http://hdl.handle.net/1893/11916> [Accessed 27 October 2014]

Kamp, M., (2009). Women's Studies and Gender Studies in Central Asia: Are We Talking to One Another.CENTRAL EURASIAN STUDIES REVIEW., 8 (1), 2.[online] Available from: $<$ http://www.brianglynwilliams.com/pdfs/C ESR_06_12.pdf > [Accessed 27 July 2015]

Kauhanen, A., \& Napari, S. (2015). Gender differences in careers. Annals of Economics and Statistics/Annales d'Économie et de Statistique, (117/118), 61-88.

Kelly, E.L., Moen, P. \& Tranby, E., (2011). Changing workplaces to reduce work-family conflict: schedule control in a white-collar organization, American Sociological Review,76(2),265-90.[online] Available from:

<http://www.ncbi.nlm.nih.gov/pmc/articles/ PMC3094103/> [Accessed 20 October 2014]

Kirchmeyer, C., (2002). Gender differences in managerial careers. Journal of Business Ethics, 37, 5-24.[online] Available from: <http://link.springer.com/article/10.1023\%2 FA\%3A1014721900246\#page-1> [Accessed 03 November 2014]

Labour Code of the Republic of Uzbekistan.,(2015). Article 234.Available from:

$<$ http://www.lex.uz/pages/getact.aspx?lact_ id $=145261>$ [Accessed 20 November 2015]

Lane, N., (1999). Why are there so few women in science? Nature debates, 9 September. Available from:<www.nature.com/nature/debates/wo men/women_frameset.html> [Accessed 13 October 2014]

LaPierre, T. A. \& Zimmerman, M. K., (2012). Career advancement and gender equity in healthcare management. Gender in Management: An International Journal, 27(2), 100-118: Emerald Insight

Limerick, B. \& Anderson, C., (1999). Female Administrators and School-Based Management New Models in an Era of Change?. Educational Management Administration \& Leadership, 27(4), 401414. [online] Available from: $<$ http://ema.sagepub.com/content/27/4/401. full.pdf+html $>$ [Accessed 24 November 2014]

Macarie, F.S. \& Moldovian, O., (2012).Gender Discrimination in Management: Theoretical and Empirical Perspectives.Transylvanian Review of Administrative Sciences, No. 35 E/2012, 153-172 [online] Available from: <http://papers.ssrn.com/sol3/papers.cfm?ab stract_id=2098052> [Accessed 23 July 2015]

Marongiu, S. \& Ekehammar, B., (1999). Internal and external influences on women's and men's entry into management, Journal of Managerial Psychology, 14 (5), 421-433 [online] Available from <http://dx.doi.org/10.1108/0268394991027 7175> [Accessed 23 September 2015]

Mavriplis, C., Heller, R., Beil, C., Dam, K., Yassinskaya, N., Shaw, M., \& Sorensen, C.,(2010). Mind the gap: Women in STEM career breaks. Journal of Technology, Management \& Innovation, 5(1), 140151.

Meyer, N., \& Hamilton, L. (2020). Female entrepreneurs' business training and its effect on various entrepreneurial factors: Evidence from a developing country. International Journal of Economics and Finance Studies, 12(1), 135-151.

Meyer, N.,\& Keyser, E., (2019). Does having children really make a difference: The case 
of South African female entrepreneurs. International Journal of Economics and Finance Studies, 11(1):64-79.

Mielach, D., (2013). How Having Kids Affects Your Career. [online]

BusinessNewsDaily.com. Available from: $<$ http://www.businessnewsdaily.com/4625gender-roles-work.html> [Accessed 11 Feb 2015]

Millar, P. E., \& Barker, J. (2020). Gender and academic promotion to full professor in Ontario. Canadian Journal of Sociology, 45(1), 47-70.

Millier, K. \& Bellamy, P., (2014). The Business Women's Association of Uzbekistan: A qualitative study of the emergence and potential influence of women's leadership in Central Asia. Journal of Eastern European and Central Asian Research (JEECAR), 1(1), p.10.

Moir, J., (2006). Tipping the scales: Talking about women in science and work-life balance. Paper presented at science policies meet reality: Gender, women, and youth in science in Central and Eastern Europe CECWYS conference, Prague, Czech Republic, 12 December.

Morley, L., (2014). Lost leaders: Women in the global academy. Higher Education Research \&Development, 3(1), 114-128. [online] Available from:

$<$ http://www.tandfonline.com/doi/full/10.10 80/07294360.2013.864611\#.VbSvQfntlBc> [Accessed 03 December 2014]

O'Connor, P. \& White, K., (2011). Similarities and differences in collegiality/managerialism in Irish and Australian universities. Gender and education, 27(3), 903920.[online] Available from: <http://ulir.ul.ie/handle/10344/3087> [Accessed 13 November 2014]

Parker, R. \& Pollock, G., (2013). Old mistresses: Women, art, and ideology. IB Tauris.[online] Available from:

<https://books.google.co.uz/books?id=dWU bawAAQBAJ>[Accessed 29 November 2014]

Petersen, T. \& Saporta.I., ( 2004). The Opportunity Structure for Discrimination. American Journal of Sociology 109, no.4: 852-901.
Robson, C. (2002). Real World Research: A Resource for Social Scientists and Practitioner-Researchers (2nd ed.). Oxford: Blackwell Publishers Ltd.

Sharma, S., \& Kaur, R. (2019). Glass ceiling for women and work engagement: The moderating effect of marital status. FIIB Business Review, 8(2), 132-146.

Simoni, M. K., Mu, L., \& Collins, S. C. (2017). Women's career priority is associated with attitudes towards family planning and ethical acceptance of reproductive technologies. Human Reproduction, 32(10), 2069-2075.

Survey Monkey., (2015).Response rate. [online] Available from: Survey Monkey $<$ http://help.surveymonkey.com/articles/en US/kb/Response-Rate-Tips-How-toimprove-low-response-rates> [Accessed 23 July 2015]

Ridgeway, C. L., (2001). Gender, status, and leadership. Journal of Social Issues,57(4), 637-655. [online] Available from: Wiley Online

Library.<http://www.readcube.com/articles/ 10.1111\%2F0022-4537.00233>[Accessed 20 December 2014]

Ridgeway, C. L. (2014). Why Status Matters for Inequality. American Sociological Review, 79(1), 1-16.

https://doi.org/10.1177/0003122413515997 [Accessed 14 July 2021]

Robson, C., (2002). Real-world research, 2. Oxford: Blackwell publishers.[online] Available from: <http://www.dem.fmed.uc.pt/Bibliografia/Li vros_Educacao_Medica/Livro34.pdf> [Accessed 23 December 2015]

Saunders, M., Lewis, P. \& Thornhill, A., (2003). Research Methods for Business Students. (3rd edition) London: Pearson Education (650.017)

Selzer, R. \& Robles, R. (2019). Every Woman Has a Story to Tell: Experiential Reflections on Leadership in Higher Education, Journal of Women and Gender in Higher Education, 12:1, 106-124, DOI: 10.1080/19407882.2018.1534246

Somach, S. \& Rubin, D., (2010). Gender Assessment USAID/Central Asian Republics. 
[online] DevTech Systems, Inc.Available from:

$<$ http://pdf.usaid.gov/pdf_docs/PNADS880.p $\mathrm{df}>$ [Accessed 25 July 2015]

Stone, P., (2007). Opting out?: Why women really quit careers and head home. University of California Press.

Tastanbekova, K., (2020). Prestige, status, and esteem of educational occupation in Kazakhstan: temporal, regional, and gender analysis of payroll data. Journal of Eastern European and Central Asian Research (JEECAR), 7(2), pp.175-190.

Tharenou, P.,(1997). Explanations of Managerial Career Advancement. Australian Psychologist, 32: 19-28. [online] Available from:<http://www.readcube.com/articles/1 0.1080\%2F00050069708259614> [Accessed 21 October 2014]

Tharenou, P., (1999). Gender differences in advancing to the top, International Journal of Management Reviews, 2, 1-22. [online] Available from:<http://www.readcube.com/articles/1 0.1111\%2F1468-2370.00008> [Accessed 20 October 2014]

The National Archive, (2015).Maternity Pay and Leave. [online] Available from:< https://www.gov.uk/maternity-payleave/overview>[Accessed 20 November 2015]

The World Bank, (2020). School enrollment, tertiary (gross), gender parity index (GPI)https://data.worldbank.org/indicator/S E.ENR.TERT.FM.ZS?locations=UZ [Accessed 15 July 2021]

The World Bank, (2021). Labor force participation rate, male (\% of male population ages 15+). [online] Available from: The World Bank Group< https://data.worldbank.org/indicator/SL.TLF. CACT.MA.ZS? locations=UZ $>$ [Accessed 15 July 2021]

The World Bank, (2021). Labor force participation rate, female (\% of female population ages $15+$ ). [online] Available from: The World Bank Group< https://data.worldbank.org/indicator/SL.TLF. CACT.FE.ZS?locations=UZ> [Accessed 15 July 2021]
The World Bank, (n.d.). Gender at Work: Emerging messages. Gender and Development. World Bank Group. [online] United Nations. Available from: The World Bank Group <http://www.worldBank.org/content/dam/ Worldbank/document/Gender/Gender\%20at \%20Work,\%20Emerging\%20Messages,\%200ff icial.pdf $>$ [Accessed 26 July 2015]

Turkmen, B., \& Eskin Bacaksiz, F. (2021). Does the glass elevator still work: A descriptive and cross-sectional study in the context of gender in Turkey. Journal of Nursing Management.

UN, (2010). Millennium Development Goals 2015: We can end poverty.UN Department of Public Information-DPI/2650 C.[online] UN Available from:<http://www.un.org/millenniumgoals/ pdf/MDG_FS_3_EN.pdf $>$ [Accessed 26 July 2015]

UNESCO, (2008). Regional overview: Central and Eastern Europe and Central Asia. Education for All. Global Monitoring Report. [online] UNESCO Available from:< $:<$ http://en.unesco.org/gemreport/sites/gemreport/files/157316E.pdf $>$ [>[Accessed 25 July 2015]

Uzbekistan | Gender | World Bank Development Indicators. (2021). Retrieved 16 July 2021, from https://tradingeconomics.com/uzbekistan/in dicators-wb-data.html?g=gender

Véliz, D., (2019) Experiences of International Women Faculty at One Striving University, Journal of Women and Gender in Higher Education, DOI: 10.1080/26379112.2019.1681006

Weisshaar, K. (2017). Publish and perish? An assessment of gender gaps in promotion to tenure in academia. Social Forces, 96(2), 529-560.

Welter, F., Smallbone, D., \& Mirzakhalikova, D. (2017). Women entrepreneurs between tradition and modernity-the case of Uzbekistan. In Enterprising women in transition economies (pp. 59-80). Routledge.

White, K., Carvalho, T., \& Riordan, S. (2011). Gender, power and managerialism in 
universities. Journal of Higher Education

Policy and Management, 33(2), 179-188.

Williams, C.L., (1992). The Glass Escalator:

Hidden Advantages for Men in the "Female"

Professions. Social Problems, 39(3),253-267.
WFUNA, (2015). Millennium Development Goal \#3.[online] United Nations. Available from: $<$ http://www.wfuna.org/mdg-genderequality $>$ [Accessed 25 July 2015]

\section{Appendix A}

An online copy can be found following the link http://goo.gl/forms/pxVCQvR2NK

\section{Questionnaire}

Thank you for agreeing to participate in my study!

I am conducting an anonymous survey which is aimed at investigating whether gender matters in career progression at Westminster International University in Tashkent (WIUT). It will take you less than 5 minutes to answer the questions below. Please note that by filling this form in you give your consent that any information provided by you will be used for the author's research findings and analysis exclusively. I highly appreciate your cooperation.

Thank you in advance!

Please, tick the relevant option(s).

\section{Your gender}

Male

Female

\section{Marital status}

Married or cohabiting

Previously married

Never married

\section{Number of dependent children}

0

$1-2$

3-4

5 and more

\section{Your highest education degree}

Bachelor's

Master's

Doctorate 


\section{Number of (calendar) years employed at WIUT}

less than 1 year

$1-4$

$5-8$

$9-13$

\section{Subject area you work at}

English language and Personal Development

Economics/Finance

Business/Marketing

Business Information Systems

Commercial Law

\section{Your entering position}

(the position when you started working at WIUT)

Lecturer

Module Leader

Course Leader

Subject Area Leader

Deputy Dean

Dean

Deputy Rector

Rector

\section{Your current position}

Lecturer

Module Leader

Course Leader

Subject Area Leader

Deputy Dean

Dean

Deputy Rector

Rector

9. Have you ever applied for a higher position?

No, I have not.

Yes, I have. It was successful.

Yes, I have. It was not successful.

10. Have you ever had more than one year career break for family reasons?

Yes

No 
11. Please, indicate whether you agree or disagree with the following statements

(If you agree, please put tick. You can choose several options)

I do not feel discriminated against in obtaining a higher position

I feel discriminated against in obtaining a higher position because of my gender

I feel discriminated against in obtaining a higher position because I have dependent children

I feel discriminated against in obtaining a higher position because of my qualification

I feel discriminated against in obtaining a higher position because I do not have enough experience

Other (please specify):

12. Please, tick the statement which you consider the most suitable for you

I aspire to get a higher position in next 5 years

I aspire to get a higher position in next 10 years

I aspire to get a higher position in next 15 years

I do not aspire to get a higher position

13. Which statement reflects your attitude towards gender balance in management?

I prefer mainly male managers

I prefer mainly female managers

I have no preference

If you have any further comments, please leave them here

Thank you very much for your contribution to a current study!

CORRESPONDING AUTHOR

Irina Kerimova, email: ikerimova@wiut.uz 